\title{
ANALYSIS AND FORECASTING OF PRICE PARITIES FOR VEGETABLES IN SERBIA
}

\author{
Nebojša Novković 334 \\ Ljiljana Drinićc 335 \\ Dragan Ivaniševićc ${ }^{336}$ \\ Šumadinka Mihajlović337 \\ https://doi.org/10.31410/itema.2018.981
}

\begin{abstract}
The analysis and forecasting of price parities for vegetables were made in relation to the prices of cereals - wheat in Serbia. The objective of the analysis and forecasting of these parities is to forecast the relative economical (price) positions of certain vegetable crops by comparing them to agricultural (field crop) products represented by wheat as the most important field crop in Serbia.

The analysis and forecasting of the price parities was made in relation to wheat for the following vegetable crops: potato, bean, tomato, pepper, onion and cabbage.

The price parities were analyzed by means of descriptive statistics for the period 1994-2017. The analysis included the basic statistical indicators: average value of occurrence, extreme value (minimum and maximum), coefficient of variation and average annual rate of change ( $r$ ). Based on the established parity change rates ( $r$ ) in \%, the forecast was made for the period 2018-2022.

The data used in the analysis refer to the prices in Serbia. The price series in this paper are either taken from or formed on the basis of statistical publications of the Institution of Statistics of the Republic of Serbia for the relevant years. In addition to the official publications, data from the websites of the statistical institutes of the Republic of Serbia were also used as a data source.

Relative prices, i.e. parities of vegetables in comparison with wheat, as an indicator of the relative economic position of vegetables in comparison with other competitive crops, showed similar trends as the absolute, discounted prices. Slight increase of parity was noted for pepper, while the parity for bean and tomato showed significant increase. Slight decrease of parity was recorded for potato and onion. The parity for cabbage showed significant decline.
\end{abstract}

Keywords: vegetables, price parity, Serbia, forecasting

\section{INTRODUCTION}

$\mathrm{V}$ egetable production can and should play a significant role in rural development. Realistic assumptions for this hypothesis are as follows:

The time required for vegetable production is relatively short, meaning that the land can be used for 2, 3 or 4 seedlings per year, which significantly increases the capital turnover, thereby improving economic results;

\footnotetext{
${ }^{334}$ University of Novi Sad, Faculty of Agriculture, Serbia

${ }^{335}$ University of Banja Luka, Faculty of Agriculture, BiH

${ }^{336}$ Privredna akademija Novi Sad, FIMEK, Serbia

${ }^{337}$ University of Novi Sad, Faculty of Agriculture, Serbia
} 
- Vegetables are extremely important for a healthy diet;

- In the conditions in our country it is possible to grow dozens of different vegetable crops;

- Vegetable production is labour-intensive (requiring high investments in labour force and employment);

- Production of vegetables requires intensive investments (in irrigation, protected area, foil, other intermediate material);

- Vegetable production creates enormous mass of organic matter;

- Vegetable production entails the need for development of livestock production (owing to the need for organic fertilizers).

The most important economic factor in the development of agriculture is price relations (parities). There are three main types of price parities:

- Price relations between agricultural products and inputs in agriculture,

- Price relations between certain types of products within agriculture, and

- Price relations between agricultural and food products.

The price parities between certain types of products within agriculture affect the development of certain lines and branches of agriculture.

Analyses and forecasting of product characteristics of certain vegetable crops, areas, yields and annual production in Serbia and the region have been carried out by a number of authors: [1] [8].

In addition, a certain number of papers dealt with forecasting vegetable prices and their parities. The models most commonly used for forecasting were ARIMA models ([9] - [12]).

The subject of the research in this paper is the analysis and forecasting of vegetable price parities in relation to the price of wheat in Serbia.

The objective of the analysis and forecasting of these parities is to forecast the relative economic (price) position of certain vegetable crops in relation to competitive agricultural (field crop) products, i.e. cereals, represented by wheat as the most important cereal used for bread in Serbia.

The analysis and forecasting of price parities was made in relation to wheat for the following vegetable crops: potato, bean, tomato, pepper, onion and cabbage.

\section{METHOD OF RESEARCH \& DATA SOURCES}

The price parities were analyzed by means of descriptive statistics for the period 1994-2017. The analysis included the basic statistical indicators: average value of occurrence, extreme value (minimum and maximum), coefficient of variation and average annual rate of change (r). Given the values of a time series $\mathrm{Y}$ with the length $\mathrm{n}$, the average rate of change index is:

$$
G=\left(\frac{\mathrm{Y}_{n}}{\mathrm{Y}_{1}}\right)^{\frac{1}{n-1}}
$$

and the average rate of change:

$$
r=(G-1)
$$


where:

$\mathrm{r}=$ the average annual rate of change

$\mathrm{G}=$ the average annual index of change

$\mathrm{Y}_{1}=$ the absolute value of the first member of the time series

$\mathrm{Y}_{\mathrm{n}}=$ the value of the last number of the time series

$\mathrm{n}=$ the length of the series (the number of years).

Based on the established parity change rates (r) in \%, the forecast was made for the period 2018-2022.

The data used in the analysis refer to the prices in Serbia. The price series in this paper are either taken from or formed on the basis of statistical publications of the Institution of Statistics of the Republic of Serbia.

\section{RESULTS OF RESEARCH}

The study includes a descriptive statistical analysis of the price parities for each analyzed vegetable crop in relation to wheat, followed by forecasting of the parities for a five-year period based on the established average annual rates of change (r).

The discussion and conclusion include a comparative qualitative analysis of the price parities of the analyzed vegetable crops, in order to forecast a relative trend of economic importance for each vegetable crop in relation to cereals as the most represented group of field crops in Serbia.

\subsection{Potato/wheat price parity}

The descriptive statistical analysis of changes in the potato/wheat price parity in the period 1994-2017 is presented in Table 1. In the analyzed period, the value of 1 kilogram of potatoes on average corresponded to 1.42 kilograms of wheat, showing considerable variations and recording a slight rate of average decline, below one percent per year. The most favorable parity was in 2000, while the most unfavorable parity was noted in 2005. Since 2014, the potato/wheat price parity has been quite stable, around 1.35.

Table 1: Descriptive analysis of potato/wheat price parity in the period 1994-2017

\begin{tabular}{|l|c|c|c|c|c|}
\hline \multirow{2}{*}{\begin{tabular}{c} 
Vegetable \\
\cline { 3 - 4 }
\end{tabular}} & Average & \multicolumn{2}{|c|}{ Interval of variation } & \multirow{2}{\text{Variation}}{$\begin{array}{c}\text { Average } \\
\text { coefficient } \\
(\%)\end{array}$} & $\begin{array}{c}\text { rate of } \\
\text { change (\%) }\end{array}$ \\
\hline Potato & Minimum & Maximum & 2.70 & 26.61 & -0.89 \\
\hline
\end{tabular}

Figure 1 shows the original data on potato/wheat price parity and the forecast for the following five years.

The parity will slightly decrease, so at the end of the forecasting period it will decline to the level of 1.3 kilograms of wheat per kilogram of potatoes. 
Figure 1: Analysis and forecasting of potato/wheat price parity

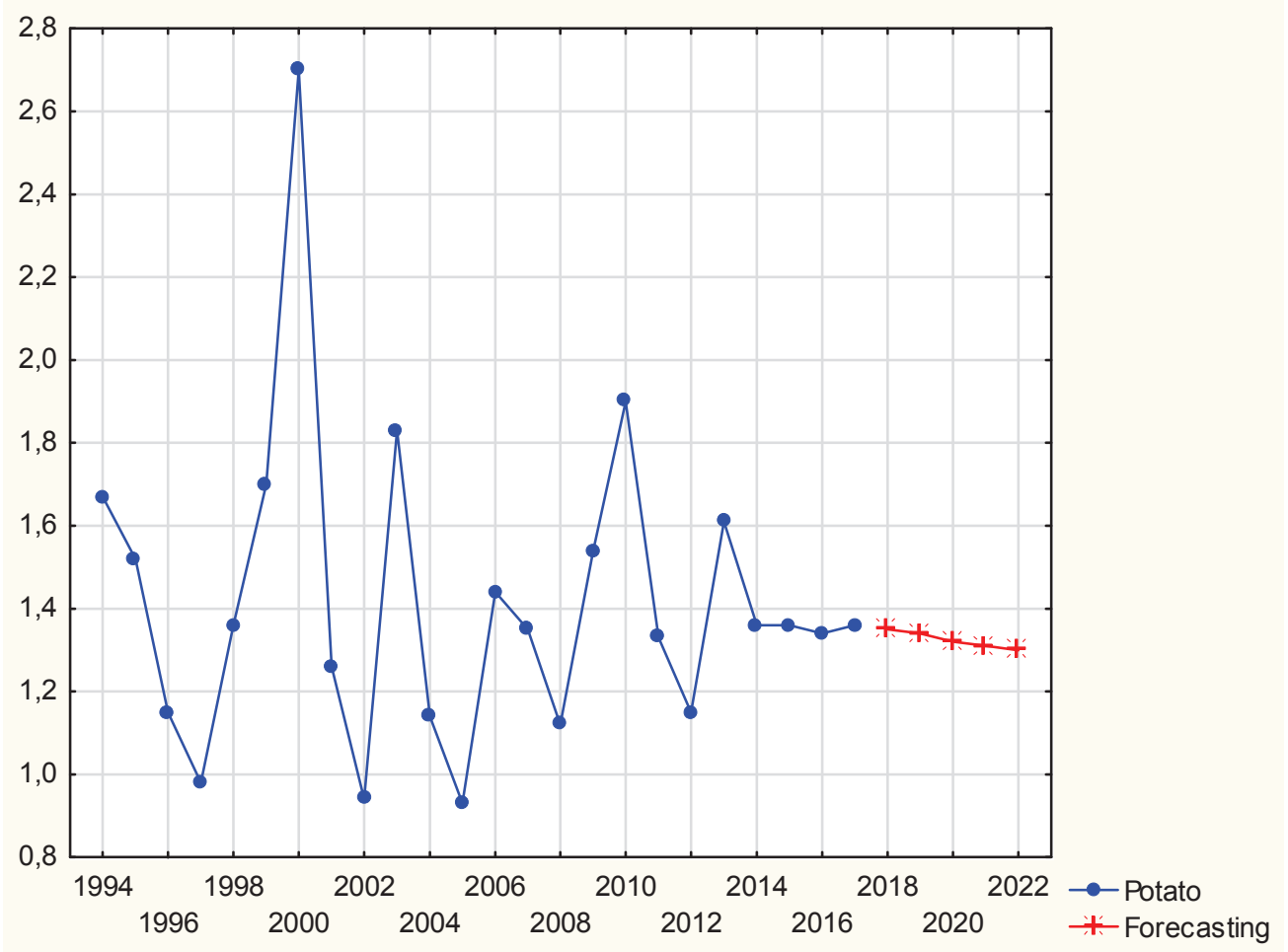

\subsection{Bean/wheat price parity}

The descriptive statistics of the bean/wheat price parity in the period 1994-2017 is presented in Table 2. In the analyzed period, 1 kilogram of beans was worth on average over 9 kilograms of wheat. The maximum value of the parity was achieved in 2014, while the minimum value was observed in 1996. The variations in parity were similar to the variations in potatoes. The bean/wheat price parity shows a moderately increasing trend.

Table 2: Descriptive analysis of bean/wheat price parity in the period 1994-2017

\begin{tabular}{|c|c|c|c|c|c|}
\hline \multirow[b]{2}{*}{ Vegetable } & \multirow[b]{2}{*}{ Average } & \multicolumn{2}{|c|}{ Interval of variation } & \multirow{2}{*}{$\begin{array}{c}\text { Variation } \\
\text { coefficient } \\
(\%)\end{array}$} & \multirow{2}{*}{$\begin{array}{c}\text { Average } \\
\text { rate of } \\
\text { change }(\%)\end{array}$} \\
\hline & & Minimum & Maximum & & \\
\hline Bean & 9.14 & 4.43 & 14.54 & 27.61 & 2.20 \\
\hline
\end{tabular}

Figure 2 shows the original data on the bean/wheat price parity and the forecast for the following five years.

The price parity will improve, so it is forecast that in 2022 it will reach the level of $11.5 \mathrm{~kg}$ of wheat per kilogram of beans, which is significantly higher compared to the average value in the analyzed period. 
Figure 2: Analysis and forecasting of bean/wheat price parity

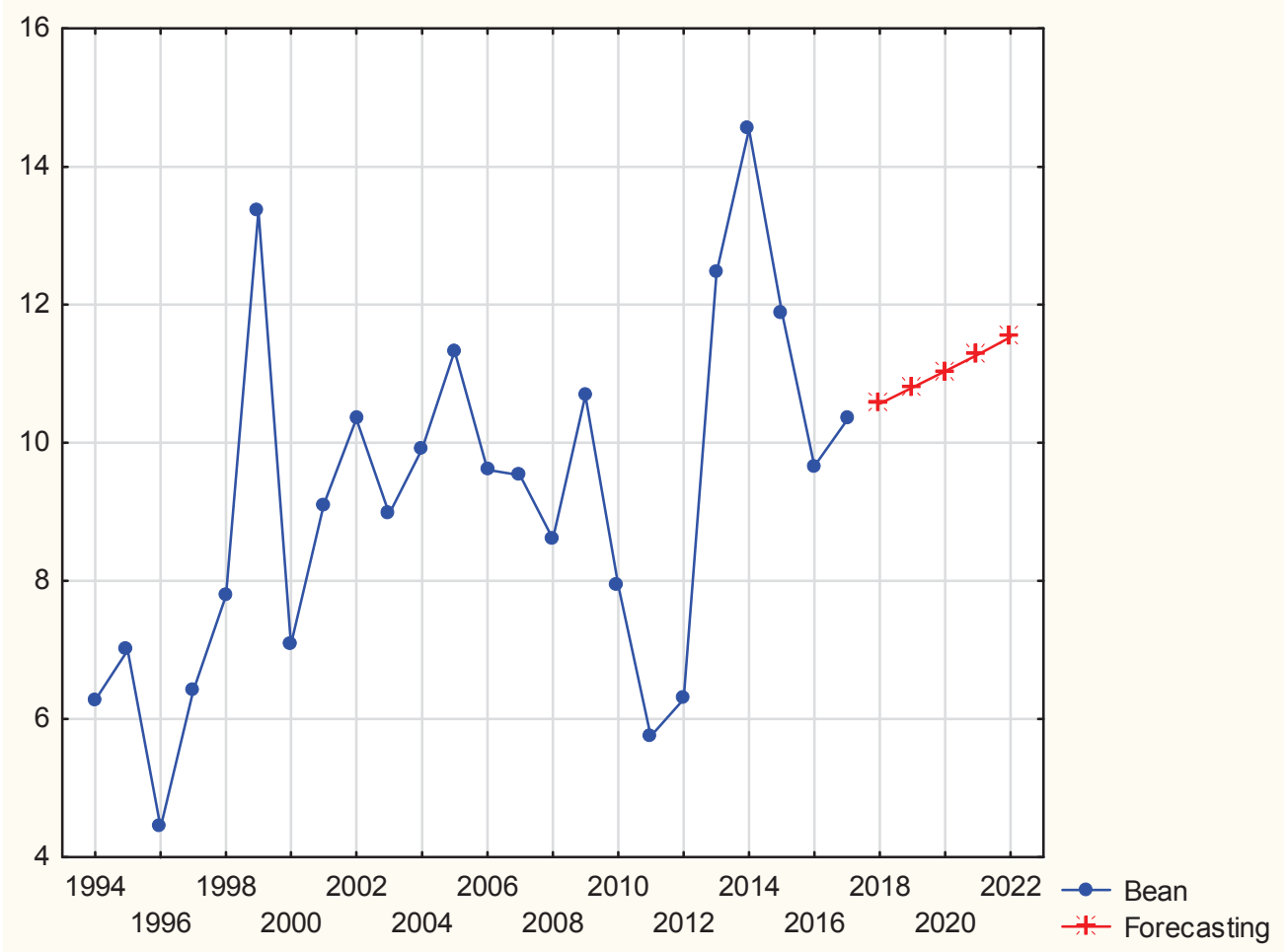

\subsection{Tomato/wheat price parity}

In the analyzed period, a kilogram of tomatoes was worth on average almost two kilograms of wheat. The tomato/wheat price parity showed extremely high variability over the years. The most favorable parity was in 2014, while the most unfavorable parity was recorded in 1996. The tomato/wheat price parity showed a positive trend in the studied period.

Table 3 presents a descriptive statistical analysis of the changes in the tomato/wheat price parity in the period 1994-2017.

Table 3: Descriptive analysis of the tomato/wheat price parity in the period 1994-2017

\begin{tabular}{|c|c|c|c|c|c|}
\hline \multirow{2}{*}{ Vegetable } & Average & \multicolumn{2}{|c|}{ Interval of variation } & \multirow{2}{\text{Variation}}{$\begin{array}{c}\text { Average } \\
\text { coefficient } \\
(\%)\end{array}$} & $\begin{array}{c}\text { rate of } \\
\text { change (\%) }\end{array}$ \\
\hline Tomato & 1.91 & 0.63 & 3.71 & 47.64 & 3.17 \\
\hline
\end{tabular}

Figure 3 presents the original data on the tomato price parity and the forecast for the following five years. In the fifth year of the forecast, the price of tomato will reach a level of 3.33 kilograms of wheat. 
Figure 3: Analysis and forecasting of tomato/wheat price parity

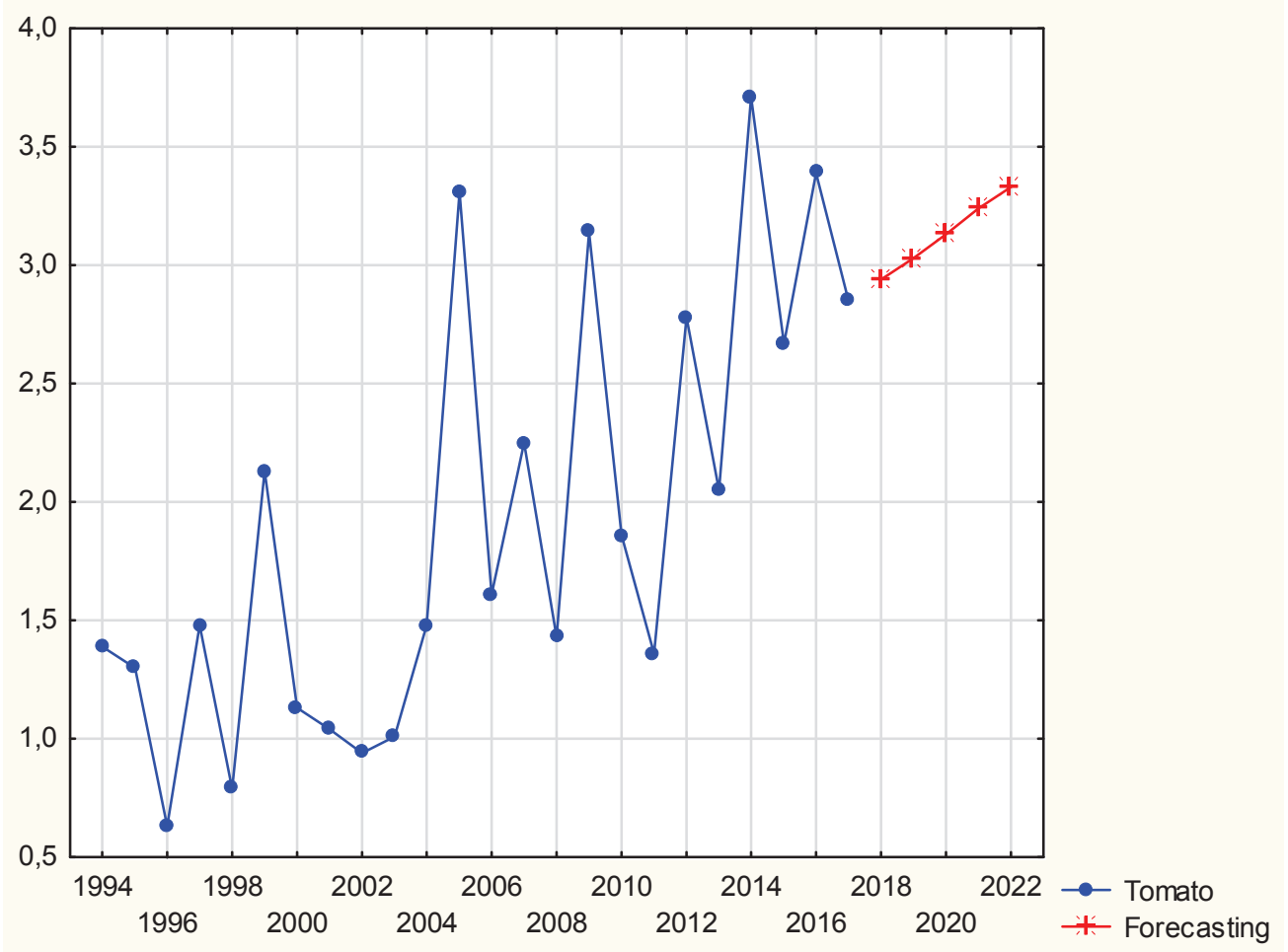

\subsection{Pepper/wheat price parity}

Descriptive statistics of the pepper/wheat price parity in the analyzed period is shown in Table 4. A kilogram of peppers was worth on average about 2.3 kilograms of wheat, with moderate variations over years. The maximum value of the parity was achieved in 2000, while the minimum parity was observed in 1997. The pepper/wheat price parity shows a slightly increasing trend.

Table 4: Descriptive analysis of the pepper/wheat price parity in the period 1994-2017

\begin{tabular}{|c|c|c|c|c|c|}
\hline \multirow{2}{*}{ Vegetable } & Average & \multicolumn{2}{|c|}{ Interval of variation } & \multirow{2}{\text{Variation}}{$\begin{array}{c}\text { Average } \\
\text { coefficient } \\
\text { rof }\end{array}$} & $\begin{array}{c}\text { Minimum } \\
\text { rate of } \\
\text { change (\%) }\end{array}$ \\
\hline Pepper & 2.29 & 1.31 & 3.29 & 26.26 & 1.13 \\
\hline
\end{tabular}

Figure 4 shows the original data on the pepper price parity and the forecast for the period 20182022.

The price parity will significantly improve, so it is forecast that in 2022 the price of peppers will reach a level of 3.43 kilograms of wheat. 
Figure 4: Analysis and forecasting of pepper/wheat price parity

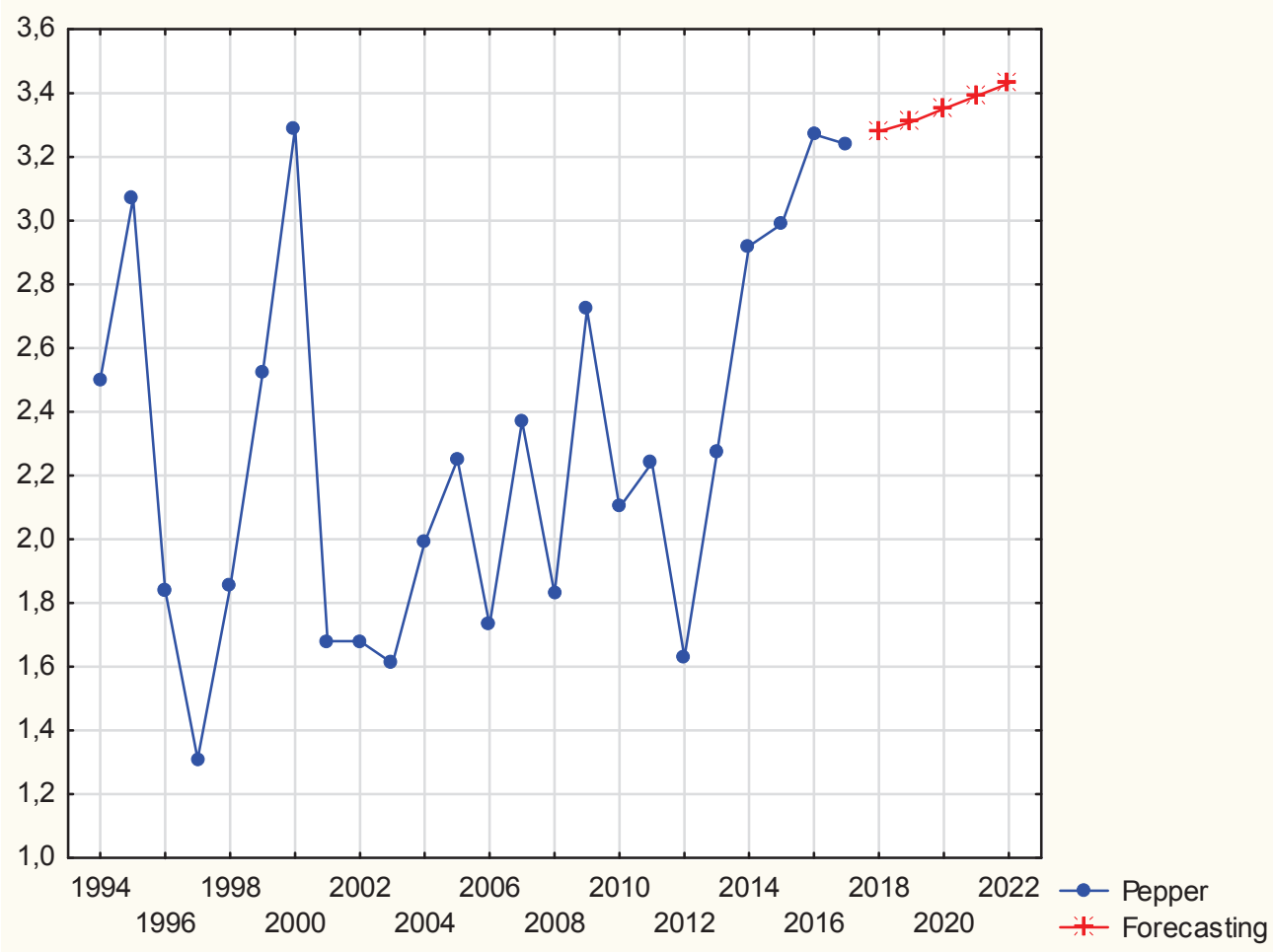

\subsection{Onion/wheat price parity}

The price of onion in the analyzed period was on average $50 \%$ higher than the price of wheat. The onion/wheat price parity shows high variability over the years. The most favorable onion/wheat price parity was in the first year of the analyzed period (in 1994), while the most unfavorable parity was in 2014 . The price parity shows a slightly downward trend.

Table 5 presents a descriptive statistical analysis of the change in onion/wheat price parity.

Table 5: Descriptive analysis of the onion/wheat price parity in the period 1994-2017

\begin{tabular}{|c|c|c|c|c|c|}
\hline \multirow[b]{2}{*}{ Vegetable } & \multirow[b]{2}{*}{ Average } & \multicolumn{2}{|c|}{ Interval of variation } & \multirow{2}{*}{$\begin{array}{c}\text { Variation } \\
\text { coefficient } \\
(\%)\end{array}$} & \multirow{2}{*}{$\begin{array}{c}\text { Average } \\
\text { rate of } \\
\text { change }(\%\end{array}$} \\
\hline & & Minimum & Maximum & & \\
\hline Onion & 1.52 & 0.87 & 4.17 & 42.80 & -1.14 \\
\hline
\end{tabular}

Figure 5 shows the original data on the onion price parity in the analyzed period and the forecast for the following five years. In the last year of the forecast period, the prices of onion will drop to the level of 1.1 kilograms of wheat, which is significantly lower compared to the average recorded during the analyzed period. 
Figure 5: Analysis and forecasting of onion/wheat price parity

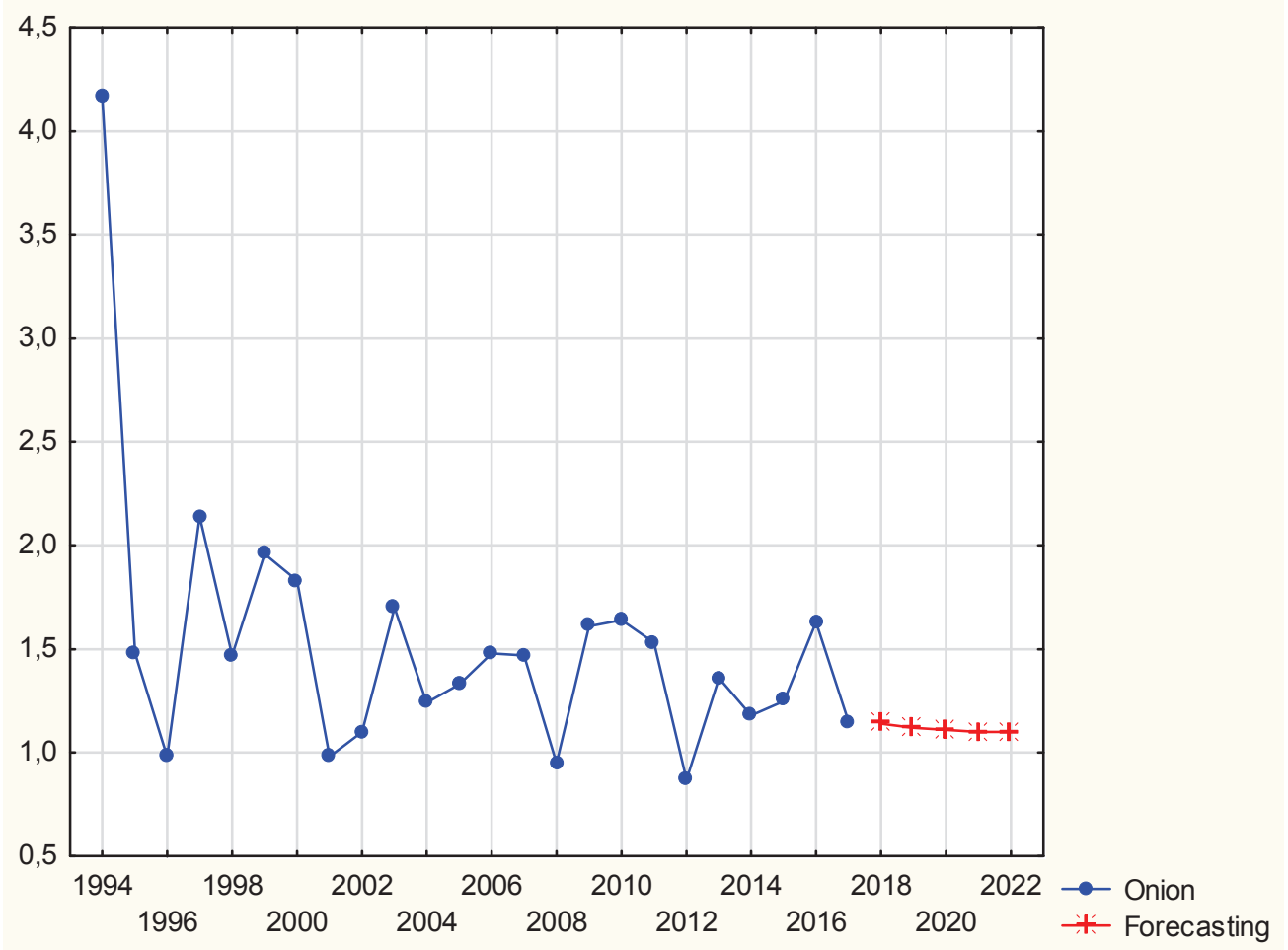

\subsection{Cabbage/wheat price parity}

In the analyzed period, a kilogram of cabbage was worth on average around $40 \%$ more than a kilogram of wheat. The cabbage price parity shows high variability over the years. The most favorable cabbage parity was recorded at the beginning of the analyzed period (in 1994), while the most unfavorable parity was in 2013 . The cabbage/wheat price parity has a downward trend.

Table 6 presents a descriptive statistical analysis of the change in the cabbage/wheat price parity in the period 1994-2017.

Table 6: Descriptive analysis of the cabbage/wheat price parity in the period 1994-2017

\begin{tabular}{|c|c|c|c|c|c|}
\hline \multirow[b]{2}{*}{ Vegetable } & \multirow[b]{2}{*}{ Average } & \multicolumn{2}{|c|}{ Interval of variation } & \multirow{2}{*}{$\begin{array}{c}\text { Variation } \\
\text { coefficient } \\
(\%)\end{array}$} & \multirow{2}{*}{$\begin{array}{c}\text { Average } \\
\text { rate of } \\
\text { change }(\%)\end{array}$} \\
\hline & & Minimum & Maximum & & \\
\hline Cabbage & 1.39 & 0.84 & 2.89 & 40.03 & -3.58 \\
\hline
\end{tabular}

The original cabbage/wheat price parity in the analyzed period and the forecast for the following five years are shown in Figure 6. It is forecast that in 2020 the price of cabbage will fall almost to the level of wheat. 
Figure 6: Analysis and forecasting of cabbage/wheat price parity

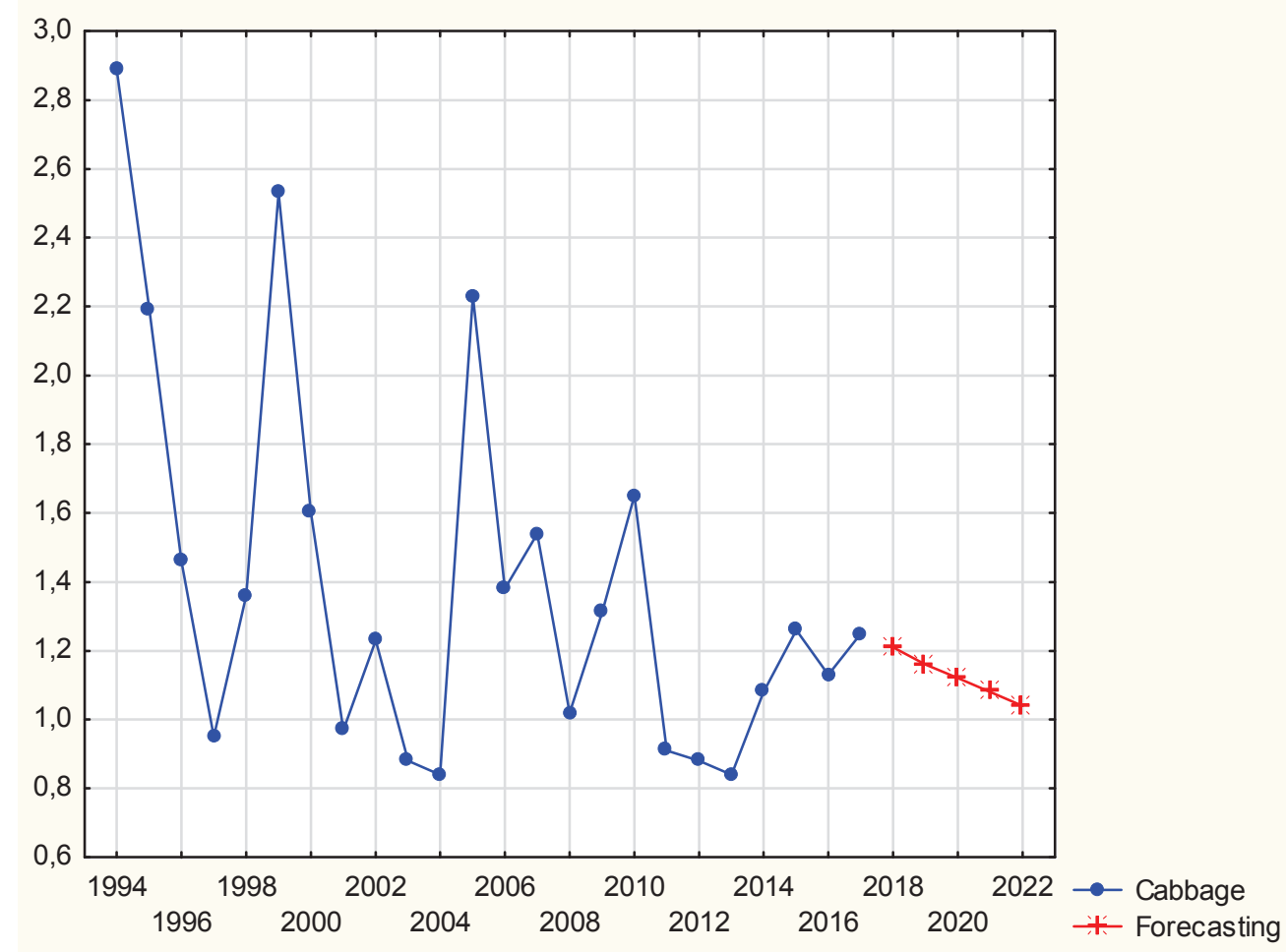

\section{DISCUSSION \& CONCLUSION}

Figure 7 shows the price parities for all analyzed vegetable crops. It can be observed that the parities of all vegetable crops (except beans) are at approximately the same level. The most favorable and unfavorable price parities were different for certain crops in different years. The most favorable parities for onion and cabbage were at the beginning of the analyzed period, i.e. in 1994. For potatoes and peppers, the most favorable year was 2000, while for beans and tomatoes it was 2014.

Forecasting the price parities for all vegetable crops in the period 2018-2022 is summarized in Figure 8.

Based on all of the above, the following conclusions can be drawn:

- Relative prices, i.e. parities of the vegetables in comparison with wheat, as an indicator of the relative economic position of the vegetables in comparison with other competitive crops, had similar tendencies as the absolute, discounted prices,

- Slight increase of parity was noted in pepper $(\mathrm{r}=1.13 \%)$,

- The parity of bean (2.20\%) and tomato (3.17\%) showed significant increase,

- Slight decrease was observed in the parity of potato (-0.89\%) and onion (-1.14\%),

- Significant decrease was observed in cabbage (-3.58). 
Figure 7: Analysis of vegetables/wheat price parity in the period 1994-2017.
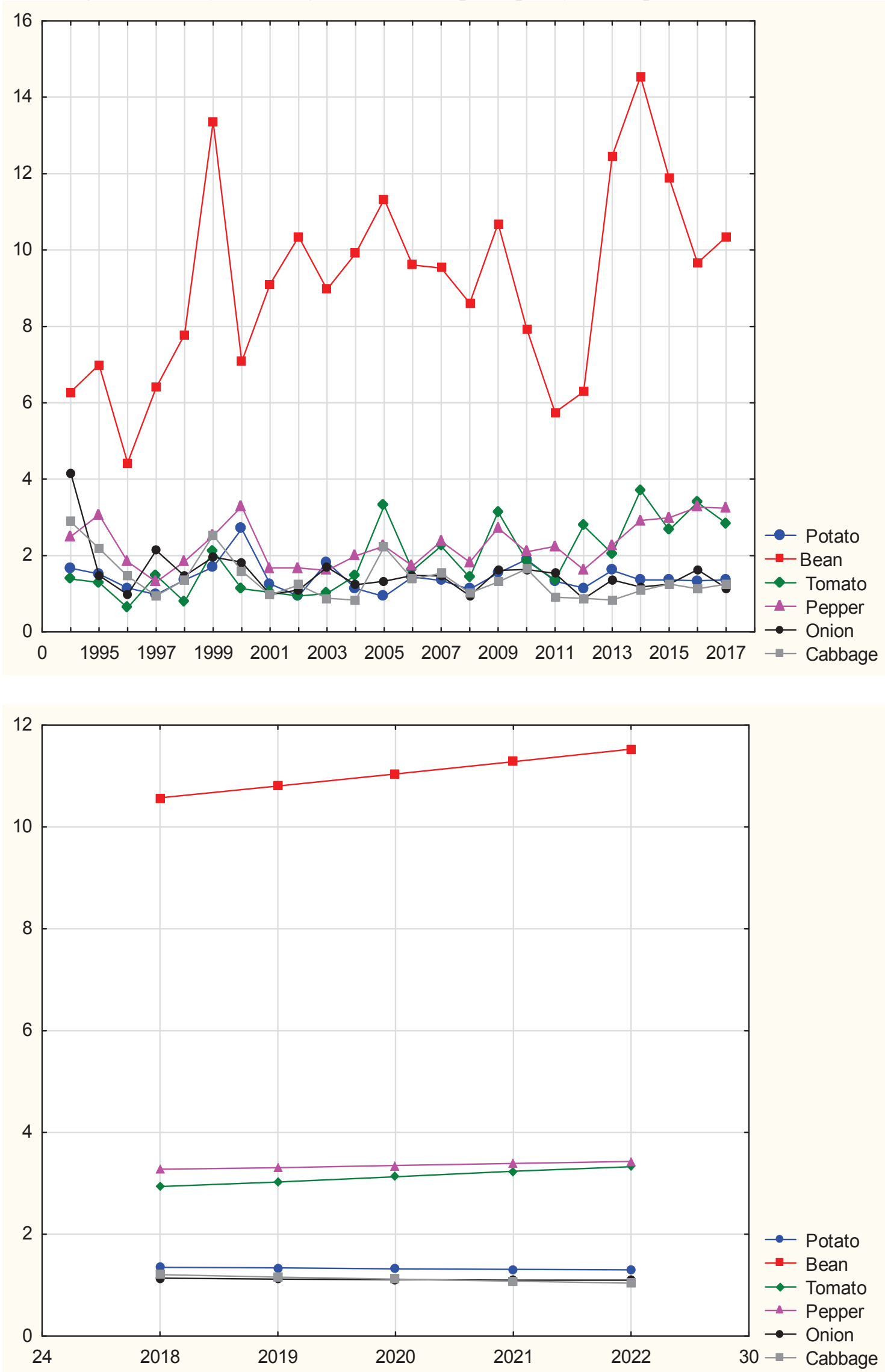


\section{REFERENCES}

[1] Ivanišević, D. (2015): Forecast of Production - Economic Parameters for Vegetable Farming in Serbia, doctoral thesis, University of Novi Sad, Faculty of Agriculture.

[2] Miljanovic Gora, Mutavdžić Beba, Novković, N., Janosevic, M. (2014): Prediction of Tomato Production Characteristics in Serbia, Book of proceedings [Elektronski izvor] / Fifth International Scientific Agricultural Symposium "Agrosym 2014", Jahorina, October 23-26; University of East Sarajevo, Faculty of Agriculture, BIH; University of Belgrade, Faculty of Agriculture, Serbia, Jahorina, str. 1056-1061; ISBN 978-99955-751-9-9.

[3] Mutavdžić Beba, Novković N., Ivanišević D. (2011): Tendencije razvoja povrtarstva u Srbiji, Agroznanje, Univerzitet u Banja Luci, Poljoprivredni fakultet, Vol.12, br. 1, str. 23 31, ISBN: 1512-6412.

[4] Mutavdžic Beba, Drinic Ljiljana, Novković, N., Ostojić, A., Rokvic Gordana (2014): Predvidjanje razvoja povrtarstva u Republici Srpskoj, "DETUROPE«, Central European Journal of Regional Development and Tourism, Volume 6, Issue 1, str.50-64, ISSN 18212506

[5] Novković, N., Mutavdžić Beba, Vukelić Nataša (2011): Vegetable production tendencies in Vojvodina, Proceedings of $22^{\text {nd }}$ International Symposium Food Safety Production, Poljoprivredni fakultet, Novi Sad, Trebinje 19-25.juna, str.163-165 ISBN: 978-86-7520219-6.

[6] Novković, N., Mutavdžic B., Drinic, Lj., Ostojic, A., Rokvic, G. (2012): Tendency Of Vegetables Development In Republic of Srpska, Third International Scientific Symposium "Agrosym Jahorina 2012" - Book of Proceedings, University of East Sarajevo, Faculty of Agricultue, BIH; University of Belgrade, Faculty of Agriculture, Serbia, Jahorina, str. 656661; ISBN 978-99955-751-0-6

[7] Novković, N., Mutavdžić Beba, Ilin Ž., Ivanišević D. (2013): Forecasting of Potato Production, Book of Abstracts, II International and XVIII scientific conference of agronomists of Republic of Srpska, Faculty of Agriculture, University of Banjaluka; Biotechnical faculty, University of Ljubljana, Trebinje 26-29.3, str. 90-91 ISBN 97899938- 93-26-4

[8] Novković, N., Beba Mutavdžić, Ilin, Ž., Lazić, D. (2015): Vegetables Production Tendencies in the EU Countries - Introductory lecture, Book of Abstracts, IV International Symposium and XX Scientific Conference of Agronomists of Republic of Srpska, page 161-162; ISBN 978-99938-93-30-1

[9] Ivanišević, A., Mutavdžić, B., Novković, N., Vukelić, N. (2015): Analysis and prediction of tomato price in Serbia, Ekonomika poljoprivrede, Institut za ekonomiku poljoprivrede, Beograd, Vol. LXII, No. 4 (899-1178), str.951-961, ISSN 0352-3462

[10] Mutavdžić, B., Novković, N., Vukelić, N., Radojević, V.(2016): Analysis and prediction of prices and price parities of corn and wheat in Serbia, Journal on processing and energy in agriculture Vol.20, No. 2, str. 106-108, Novi Sad ISSN 1821-4487

[11] Novković, N., Mutavdžić, B., Ivanišević, D., Matković, M. (2016): Analysis and prediction of cabbage price in Serbia, Book of Abstracts, 5th International Symposium on agricultural sciences, p. 90, February 29 - March 3, Banja Luka, Bosnia and Herzegovina, ISBN 978- 99938-93-37-0

[12] Novković, N., Mutavdžić Beba (2016a): Analysis and forecasting of bean prices in Serbia, Proceedings of papers: Policy and Economics for Sustainable Agricultural and Rural Development, AAEM 10 ${ }^{\text {th }}$ International Conference, 12-14 May, Ohrid, Association of Agricultural Economists of the Republic of Macedonia p.195-203, ISBN 978-9989-23587-0 